\title{
ZINC OXIDE NANOPARTICLES AMELIORATE ALUMINUM CHLORIDE-INDUCED HEPATO-RENAL OXIDATIVE STRESS AND INFLAMMATION IN RATS
}

\author{
SAHAR M. MAHMOUD ${ }^{*}$, RAMI B. KASSAB ${ }^{2}$, AHMED E. ABDEL MONEIM³
}

${ }^{1}$ Assistant Professor of Physiology at Department of Zoology, Faculty of Science, Cairo University, Cairo, Egypt, ${ }^{2}$ Assistant Professor of Physiology at Department of Zoology and Entomology, Faculty of Science, Helwan University, Cairo, Egypt, ${ }^{3}$ Professor of Physiology at Department of Zoology and Entomology, Faculty of Science, Helwan University, Cairo, Egypt

Email: sahar@sci.cu.edu.eg

Received: 22 Aug 2019, Revised and Accepted: 18 Nov 2019

\section{ABSTRACT}

Objective: The present study was designed to evaluate the effect of zinc oxide nanoparticles (ZnO NPs) on Aluminum chloride $\left(\mathrm{AlCl}_{3}\right)$-induced hepatorenal injury.

Methods: Animals were divided into, I-control group; rats received saline, $\mathrm{II}_{-} \mathrm{AlCl}_{3}$ group; animals received $100 \mathrm{mg} \mathrm{AlCl} 3 / \mathrm{kg}$ body weight, III-ZnO NPs group; rats received $10 \mathrm{mg} \mathrm{ZnO} \mathrm{NPs/kg} \mathrm{body} \mathrm{weight,} \mathrm{and} \mathrm{IV} \mathrm{group} \mathrm{ZnO} \mathrm{NPs+AlCl} 3$. All rats were administered their respective doses daily for $6 \mathrm{w}$. Hepatorenal function parameters in sera; aminotransferases, bilirubin, urea, and creatinine were estimated. Lipid peroxide level and nitrite $\backslash$ nitrate ratio, glutathione content, glutathione peroxidase, glutathione reductase, catalase, superoxide dismutase activities and interleukin- $1 \beta$, tumor necrosis factor- $\alpha$ levels were determined in both tissues. The histopathological and the immunohistochemical investigations of nuclear factor-kB expression were carried out.

Results: $\mathrm{ZnO} \mathrm{NPs}$ treatment to $\mathrm{AlCl}_{3}$-intoxicated rats significantly reduced $\mathrm{Al}$ accumulation $(\mathrm{at} \mathrm{p}<0.05)$ in the hepatorenal tissue and increased zinc accumulation (at $\mathrm{p}<0.05$ ) in liver and kidney, respectively, with respect to $\mathrm{AlCl}_{3}$-group, thus inhibiting oxidative stress and inflammation parameters represented by lipid peroxidation and nitric oxide levels (at $\mathrm{p}<0.05$ ) compared to $\mathrm{AlCl}_{3}$ group and elevated antioxidant parameters (at $\mathrm{p}<0.05$ ), compared to $\mathrm{AlCl}_{3}$ treated group, while suppressed interleukin- $1 \beta$, tumor necrosis factor- $\alpha$ levels $(a t p<0.05)$ and the nuclear factor-kB activation in liver and kidney, especially in the kidney if compared to $\mathrm{AlCl}_{3}$-treated group. Hepatorenal function indices indicated significant decreases compared to $\mathrm{AlCl}_{3}$ group (at $\mathrm{p}<0.05$ ).

Conclusion: Results indicated the ameliorative effect of ZnO NPs on aluminum-induced hepato-renal damage.

Keywords: Zinc nanoparticles, Aluminum, Inflammation, Oxidative stress, Liver, Kidney

(C) 2020 The Authors. Published by Innovare Academic Sciences Pvt Ltd. This is an open-access article under the CC BY license (http://creativecommons.org/licenses/by/4.0/) DOI: http://dx.doi.org/10.22159/ijpps.2020v12i1.35956. Journal homepage: https://innovareacademics.in/journals/index.php/ijpps

\section{INTRODUCTION}

Aluminum (Al) represents about $8 \%$ of the total mineral constituents of the earth's crust and classified among the most harmful toxicants in the environment [1]. Humans are exposed mainly to Al through drinking water, food additives, and packaging, cooking utensils, deodorants and medicines [2]. Al accumulates in different organs causing neurological, respiratory, immunological, skeletal and hematopoietic problems [3]. Reports indicated bile duct hyperplasia, liver fatty degeneration and a disturbance in transaminases and alkaline phosphatase activities following Al-intoxication [4, 5]. Chronic administration of Al-induced changes in the morphological structure of glomeruli and proximal tubular cells and affected the levels of kidney function parameters [6]. Oxidative stress is an important mechanism involved in Al-induced hepato-renal toxicity, through enhanced lipid peroxidation, nitric oxide formation and depressed cellular glutathione $[5,7]$.

Metal oxide nanoparticles received attention in medicine, for the prevention and treatment of diseases characterized by free radicals production [8]. Zinc oxide nanoparticles (ZnO NPs) have been used in different industrial products including textiles, paints, toothpaste, cosmetics, and bio-imaging probes. They were also used in genedelivery drugs and as a food additive due to their antibacterial and antifungal properties [9-11]. ZnO NPs were used for their antioxidant activities [12] but could also induce cytotoxic effects [13].

As $\mathrm{Al}$ is detoxified in the liver and excreted mainly by the kidneys, the present study was designed to evaluate the role of $\mathrm{ZnO} \mathrm{NPs}$ against $\mathrm{Al}-$ induced hepato-renal toxicity in rats, through estimation of Zinc and Al accumulation in liver and kidney, measurement of both organs function, oxidative stress and inflammatory status and histopathological investigation of hepato-renal tissue and immunohistochemical examination of nuclear factor-kappa B (NF-kB) protein expression in both tissues.

\section{MATERIALS AND METHODS}

\section{Chemicals}

Aluminum chloride $\left(\mathrm{AlCl}_{3}\right)$ anhydrous (CAS number, 7446-70-0) and zinc oxide nanoparticles (ZnO NPs), $<100 \mathrm{~nm}$ particle size (TEM), $\leq 40$ $\mathrm{nm}$ average particle size (CAS number, 1314-13-2) were obtained and purchased from Sigma-Aldrich (St. Louis, MO, USA). Chemicals and reagents used throughout the experiment were of analytical grade.

\section{Animals and experimental design}

Male Wistar rats of ten w old (200-220g) were obtained from the Holding Company for Biological Products and Vaccines (VACSERA) Cairo, Egypt. Animals were housed in wire polypropylene cages in a room under standard laboratory conditions (12h light-dark cycle; $25 \pm 2{ }^{\circ} \mathrm{C}$ ) and were provided with water and animal standard diet ad libitum, as described [14], and allowed to acclimatize for seven d before experiment practices. Rats were divided into four groups $(n=7$ rats in each): I-control group (CNT); animals were received oral saline daily, $\mathrm{II}-\mathrm{AlCl}_{3}$ treated group; rats were received daily oral $\mathrm{AlCl}_{3} 100$ $\mathrm{mg} / \mathrm{kg}$ body weight, III-ZnO NPs treated group; rats have received $\mathrm{ZnO}$ $\mathrm{NPs} 10 \mathrm{mg} / \mathrm{kg}$ body weight, orally, once, and in $\mathrm{ZnO} \mathrm{NPs}+\mathrm{AlCl}_{3}$ treated group, rats were administered $10 \mathrm{mg} / \mathrm{kg}$ of $\mathrm{ZnO}$ NPs one h prior to 100 $\mathrm{mg} / \mathrm{kg}$ of $\mathrm{AlCl}_{3}$. All rats have received their respective doses daily for 6 w. The present study was approved by the Animal Ethical Committee of Helwan University (Cairo, Egypt; approval no. HU2017/Z/09), and was conducted by the NIH Guidelines for the Care and Use of Laboratory Animals $[15,16]$.

\section{Handling of tissues}

Animals of all groups were sacrificed after $24 \mathrm{~h}$ of the last administration, and blood was collected in sterilized centrifuged tubes, 
and then centrifuged at $3000 \mathrm{pm}$ for $10 \mathrm{~min}$ to separate serum for biochemical assays. Liver and kidney from rats of all groups were quickly dissected and washed with ice-cold phosphate buffer $(0.05 \mathrm{M}$, $\mathrm{pH}$ 7.4) then subsequently, small pieces from each tissue (100 mg) were homogenized in cold phosphate buffer $(0.05 \mathrm{M}, \mathrm{pH} 7.4)$, and centrifuged at $3000 \mathrm{rpm}$ for $10 \mathrm{~min}$ at $4{ }^{\circ} \mathrm{C}$. The resulting supernatant of all tissue samples from all groups was used for the determination of biochemical parameters.

\section{Measurement of $\mathrm{Al}$ and $\mathrm{Zn}$ concentration in the liver and kidney of rat}

The concentration of $\mathrm{Al}$ and $\mathrm{Zn}$ in the liver and kidney tissues was assessed using the standardized procedure [17]. In brief, liver and kidney tissue samples were weighed and dried in an oven at $100{ }^{\circ} \mathrm{C}$ for $24 \mathrm{~h}$. The dried samples were digested with $2 \mathrm{M}$ nitric acid and $2 \mathrm{M}$ hydrochloric acid at $150{ }^{\circ} \mathrm{C}$ for $6 \mathrm{~h}$. The samples were diluted with deionized $\mathrm{H}_{2} \mathrm{O}$ to a final volume of $50 \mathrm{ml}$. Aluminum and zinc concentrations were assayed by graphite furnace atomic absorption spectrophotometry (GFAAS; Perkin-Elmer 3100) at 309.3 and 213.9 $\mathrm{nm}$, respectively. Al and $\mathrm{Zn}$ concentrations were expressed as $\mu \mathrm{g} / \mathrm{g}$ of wet tissue. All analyses were run in three replicates.

\section{Biochemical parameters}

\section{Liver and kidney functions assays}

Estimation of Liver and kidney function parameters in blood sera of rats from all groups were undertaken. The enzymatic activity of alanine aminotransaminases (ALT) and aspartate aminotransferase (AST) were determined according to the method of [18], bilirubin (Bil) was evaluated according to [19], while urea and creatinine were assayed according to [20] and [21], respectively, using commercially available diagnostic kits (Biodiagnostics-Egypt) as per manufacturer's instructions.

\section{Determination of malondialdehyde and nitric oxide levels}

Hepatic and renal level of malondialdehyde (MDA; the end product of lipid peroxidation) was determined using thiobarbituric acid according to the principle procedure [22]. While the level of nitrite/nitrate (nitric oxide, NO) was assayed according to [23].

\section{Determination of non-enzymatic and enzymatic antioxidants}

Hepatic and renal tissues homogenates were used to determine glutathione (GSH) content according to the method of [24], superoxide dismutase (SOD) and catalase (CAT) activities per the procedures described [25] and [26], respectively. Whereas, glutathione peroxidase (GPx) and glutathione reductase (GR) activities were assayed according to the methods described [27] and [28], respectively.

\section{Determination of pro-inflammatory markers}

The levels of pro-inflammatory cytokines namely; tumor necrosis factor-alpha (TNF- $\alpha$ ) and interleukin-1 beta (IL-1 $\beta$ ) in hepatic and renal tissues, were determined using enzyme-linked immunosorbent assay (ELISA) methods using rat ELISA kits (CUSABIO Life Sciences, China) according to the test procedure provided by the manufacturer. All samples were run in two replicates.

\section{Histopathological examination}

Liver and kidney tissue samples from all groups were fixed for $24 \mathrm{~h}$ in $10 \%$ neutral formalin. Following the fixation, tissue samples were passed through routine procedures and embedded in paraffin blocks and sectioned (4-5 $\mu \mathrm{m})$. After paraffin was removed, specimens were stained consistently with hematoxylin and eosin for microscopic examination according to the method described [29]. Images were taken with 400x magnification using an Eclipse E200-LED (Nikon, Tokyo, Japan).

\section{Immunohistochemical analysis}

To investigate nuclear factor-Kappa $B(N F-\kappa B)$ expression in the hepato-renal tissue, sections were embedded in paraffin $(4-\mu \mathrm{m}$ thickness) and treated with $3 \%$ hydrogen peroxide-containing methanol for $10 \mathrm{~min}$ to block the endogenous peroxidase. Then, samples were incubated with the primary antibody at $4{ }^{\circ} \mathrm{C}$ overnight. Thereafter, all sections were washed with phosphate-buffered saline (PBS) and incubated with biotinylated secondary antibody labeled with horseradish peroxidase (HRP). The reactions were developed via an HRP-catalyzed reaction with diaminobenzidine (DAB), followed by counterstaining with hematoxylin. Photographs were taken with 400x magnification using an Eclipse E200-LED (Nikon, Tokyo, Japan).

\section{Statistical analysis}

All data were calculated as the mean \pm standard deviation (SD). Differences between the groups were analyzed using a one-way analysis of variance (ANOVA) followed by Tukey's post hoc test; $p$ values $<0.05$ were being regarded as statistically significant.

\section{RESULTS}

\section{Accumulation of $\mathrm{AlCl}_{3}$ and ZnO NPs in the hepato-renal tissue}

Daily oral administration of $\mathrm{AlCl}_{3}$ at dose $100 \mathrm{mg} / \mathrm{kg}$ for $6 \mathrm{w}$ resulted in a significant increase in its accumulation at $(\mathrm{p}<0.05)$ in the hepatic and renal tissues concerning the control group. Meanwhile, in the $\mathrm{ZnO}$ $\mathrm{NPs}+\mathrm{AlCl}_{3}$ group, rats pretreated with $\mathrm{ZnO} \mathrm{NPs}(10 \mathrm{mg} / \mathrm{kg})$ for the same period showed a marked decrease in $\mathrm{Al}$ accumulation as compared with $\mathrm{AlCl}_{3}$-exposed animals as illustrated in fig. 1 .
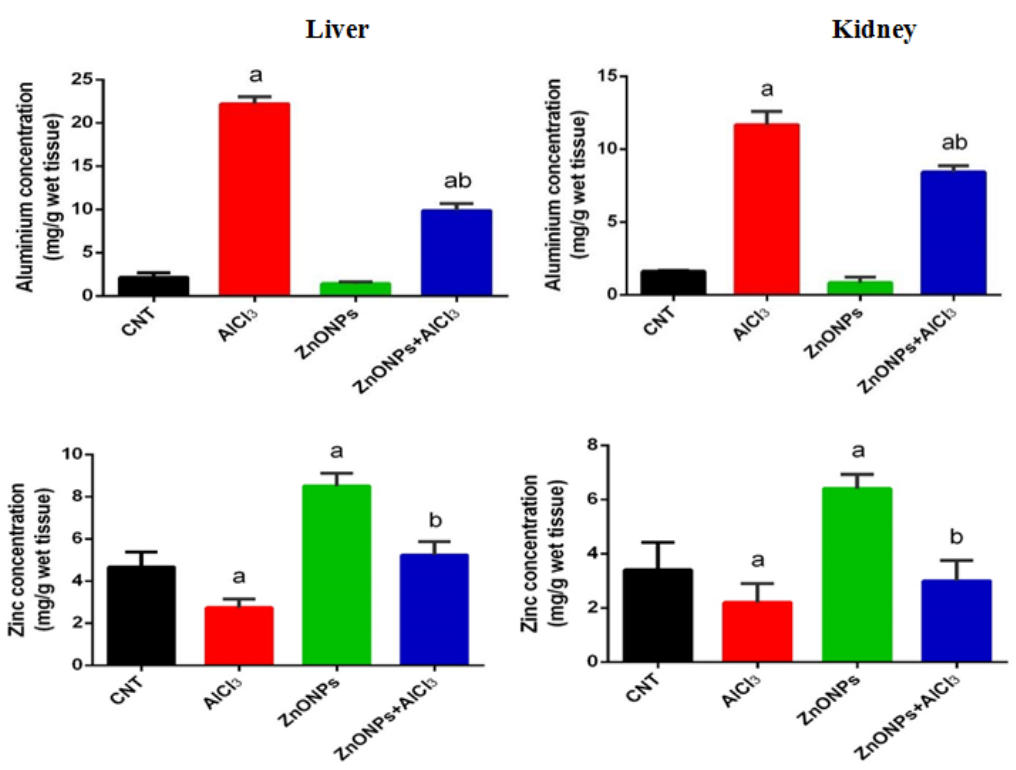

Fig. 1: Accumulation of aluminum and zinc in liver and kidney tissue after daily treatment with zinc oxide nanoparticles (ZnO NPs) and aluminum chloride, $\left(\mathrm{AlCl}_{3}\right)$ for $6 \mathrm{w}$. Data are expressed as the mean $\pm \mathrm{SD}(\mathrm{n}=7)$. ap $<0.05 \mathrm{vs}$, the Control Group; bp $<0.05 \mathrm{vs}$. the $\mathrm{AlCl}_{3}$-treated rats using Tukey post hoc test 
Effect of $\mathrm{ZnO} \mathrm{NPs}$ and/or $\mathrm{AlCl}_{3}$ treatment on hepato-renal function indices

To analyze the potential protective role of $\mathrm{ZnO} \mathrm{NPs}$ against $\mathrm{AlCl}_{3}$-induced hepato-renal toxicity, levels of liver and kidney function parameters were assessed. ALT, AST, bilirubin, urea, and creatinine levels were found to elevate with a significant change at $(\mathrm{p}<0.05)$ following $\mathrm{AlCl}_{3}$-intoxication as compared to the control group. Whereas, the levels of these physiological parameters were modulated significantly in ZnO NPs pretreated rats when compared to $\mathrm{AlCl}_{3}$-treated group as represented in table 1 .

Table 1: Effect of zinc oxide nanoparticles (ZnO NPs) and/or aluminum chloride ( $\left.\mathrm{AlCl}_{3}\right)$ after daily treated for 6 w, on liver and kidney function parameters alanine aminotransferase (ALT) aspartate aminotransferase (AST), bilirubin (Bil); urea and creatinine in sera of adult male rats

\begin{tabular}{lllll}
\hline $\begin{array}{l}\text { Experimental } \\
\text { Groups }\end{array}$ & Parameter & & & \\
\cline { 2 - 5 } & ALT(U/l) & AST (U/l) & Bil (mg/dl) & Urea(mg/dl) \\
\hline Control & $57.3 \pm 8.62$ & $82.7 \pm 10.69$ & $0.52 \pm 0.07$ & $5.60 \pm 1.15$ \\
$\mathrm{AlCl}_{3}$ & $143.7 \pm 19.60^{\mathrm{a}}$ & $192.3 \pm 16.26^{\mathrm{a}}$ & $1.63 \pm 0.25^{\mathrm{a}}$ & $15.10 \pm 2.66^{\mathrm{a}}$ \\
$\mathrm{ZnO} \mathrm{NPs}_{\mathrm{ZnO} \mathrm{NPs}+\mathrm{AlCl}_{3}}$ & $59.3 \pm 10.41$ & $87.3 \pm 14.57$ & $0.54 \pm 0.06$ & $6.92 \pm 0.22$ \\
\hline
\end{tabular}

Data are expressed as the mean \pm SD $(n=7)$, a: Significant at $\mathrm{p}<0.05$ with Respect to the Control Group, b: Significant at $\mathrm{p}<0.05$ with Respect to the AlCl3 Group

Effect of ZnO NPs and/or $\mathrm{AlCl}_{3}$ treatment on oxidant/antioxidant parameters

To study the oxidative reactions following $\mathrm{AlCl}_{3}$-intoxication and the potential antioxidant activity of ZnO NPs, the present results determined the levels of oxidants and antioxidants in the liver and kidney homogenates. As depicted in fig. $2, \mathrm{AlCl}_{3}$ treatment caused a significant $(\mathrm{p}<0.05)$ elevation in lipid peroxidation in terms of MDA and also, nitrate/nitrite levels while GSH content was depleted as compared with the corresponding control values. In contrast, ZnO NPs administration suppressed significantly elevated oxidants and increased GSH levels when compared against the $\mathrm{AlCl}_{3}$-treated group. Moreover, $\mathrm{AlCl}_{3}$ exposure inhibited significantly $(\mathrm{p}<0.05)$ the cellular antioxidant defense enzymes, including SOD, CAT, GPX, and GR, when compared versus the control values. However, the activity of these antioxidant enzymes was significantly restored toward the control value in ZnO NPs-pretreated rats (fig. 3); which reflects its antioxidant capacity against $\mathrm{AlCl}_{3}$-induced oxidative damage in the hepato-renal tissue.
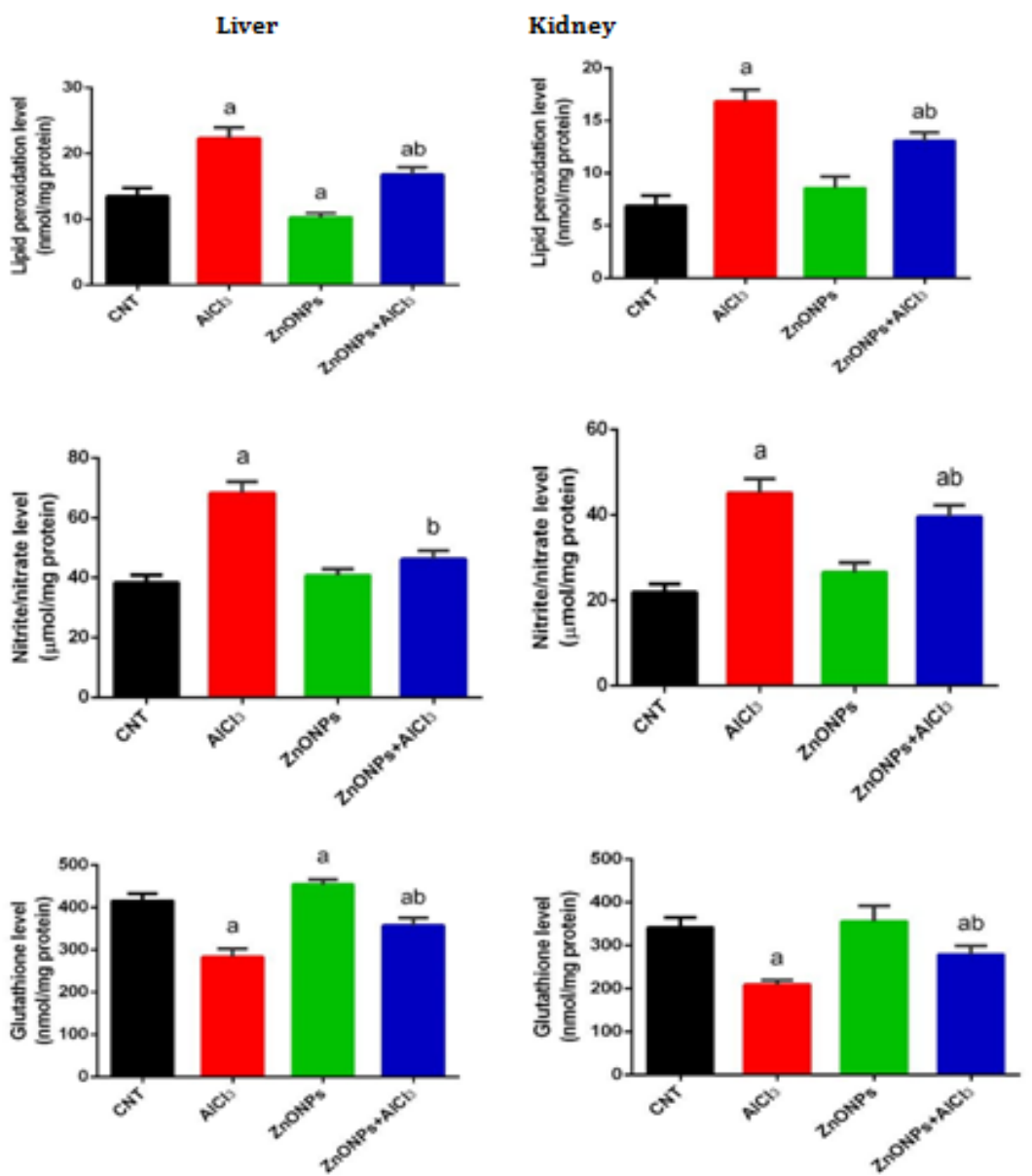

Fig. 2: Effect of zinc oxide nanoparticles (ZnO NPs) and/or aluminum chloride $\left(\mathrm{AlCl}_{3}\right)$ after daily treatment for 6 w, on lipid peroxidation (LPO), nitric oxide (NO) and glutathione (GSH) levels in liver and kidney of adult male rats. Data are expressed as the mean \pm SD (n= 7). a $\mathrm{p}<0.05$ vs. the control group; $\mathrm{b}$ p $<0.05$ vs the $\mathrm{AlCl}_{3}$-treated rats using Tukey post hoc test 
Liver
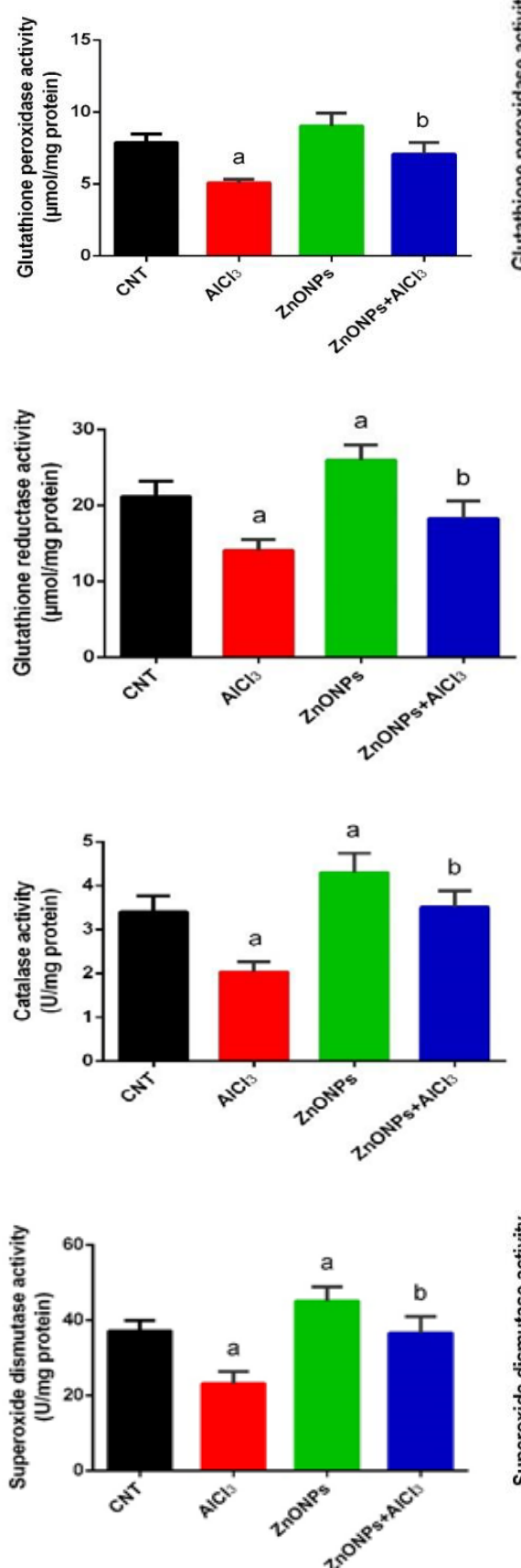

Kidney
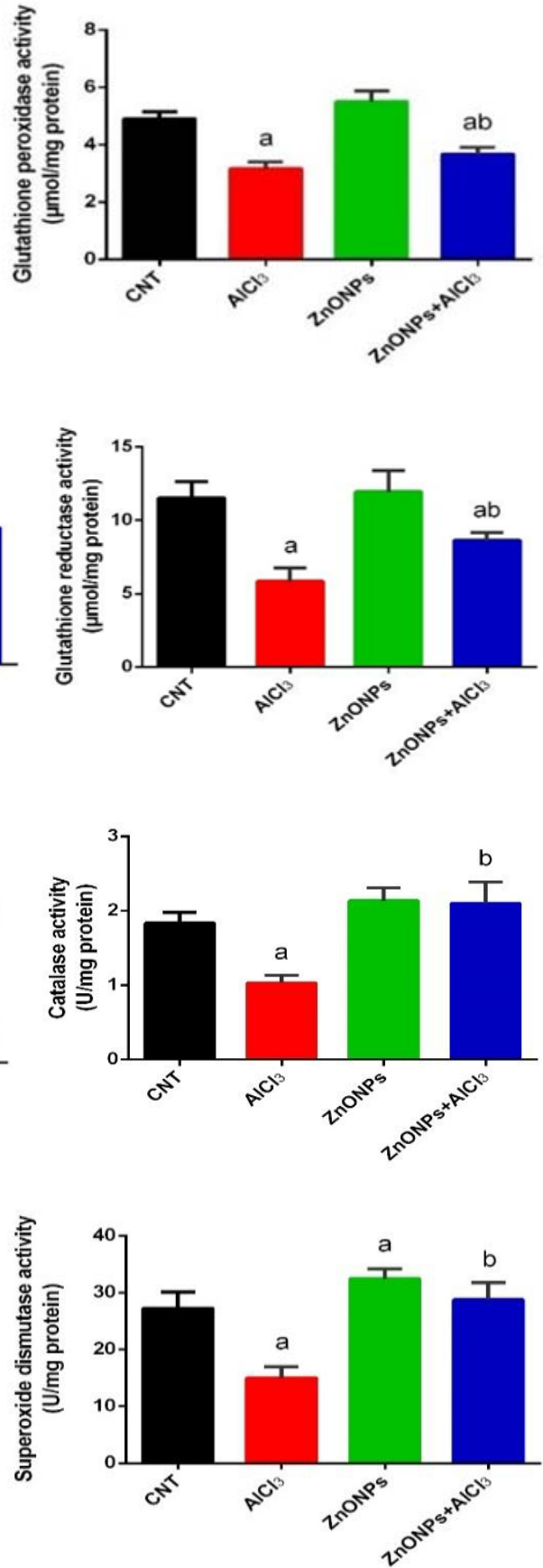

Fig. 3: Effect of zinc oxide nanoparticles (ZnO NPs) and/or aluminum chloride $\left(\mathrm{AlCl}_{3}\right)$ after daily treatment for 6 w, on antioxidant enzymes activity in liver and kidney of adult male rats. Data are expressed as the mean $\pm S D(n=7)$. a $p<0.05$ vs. the control group; $b$ p $<0.05$ vs. the $A l C l_{3}-$ treated rats using Tukey post hoc test.

\section{Effect of ZnO NPs and/or $\mathrm{AlCl}_{3}$ treatment on inflammatory response}

The present results showed that the accumulation of $\mathrm{Al}$ in the liver and kidney was found to be associated with the progression of an inflammatory response. $\mathrm{AlCl}_{3}$-treated rats exhibited a significant increase $($ at $\mathrm{p}<0.05)$ in the production of the pro-inflammatory cytokines namely; TNF- $\alpha$ and IL- $1 \beta$ concerning their control rats. Interestingly, the levels of these inflammatory cytokines were recovered towards normal values in the $\mathrm{ZnO} \mathrm{NPs}$ and $\mathrm{AlCl}_{3}$ co-administered group (fig. 4).

\section{Effect of ZnO NPs and/or $\mathrm{AlCl}_{3}$ treatment on liver histopathology}

As shown in fig. 5, the control group exhibited normal hepatocytes architecture showing well-defined central nucleus and abundant cytoplasm, while the hepatic tissue of the $\mathrm{AlCl}_{3}$-intoxicated animals indicated as previously recorded [5] by alterations in hepatic histoarchitecture after $6 \mathrm{w}$ of treatment evidenced by disrupted central vein and disarrangement of hepatic cords at most of the places and, also, vacuolated hepatocytes, leukocytes infiltration and many Kupffer cells and hepatocytes with dense and pyknotic nuclei were observed. $\mathrm{ZnO}$ NPs administration to animals for $6 \mathrm{w}$ also showed vacuolization and disrupted hepatic cords.

While $\mathrm{ZnO} \mathrm{NPs}+\mathrm{AlCl}_{3}$ treated group indicated revealed that preadministration of ZnO NPs preserved, to some extent, the hepatic tissue from these pathological alterations caused by $\mathrm{AlCl}_{3}$ exposure. 

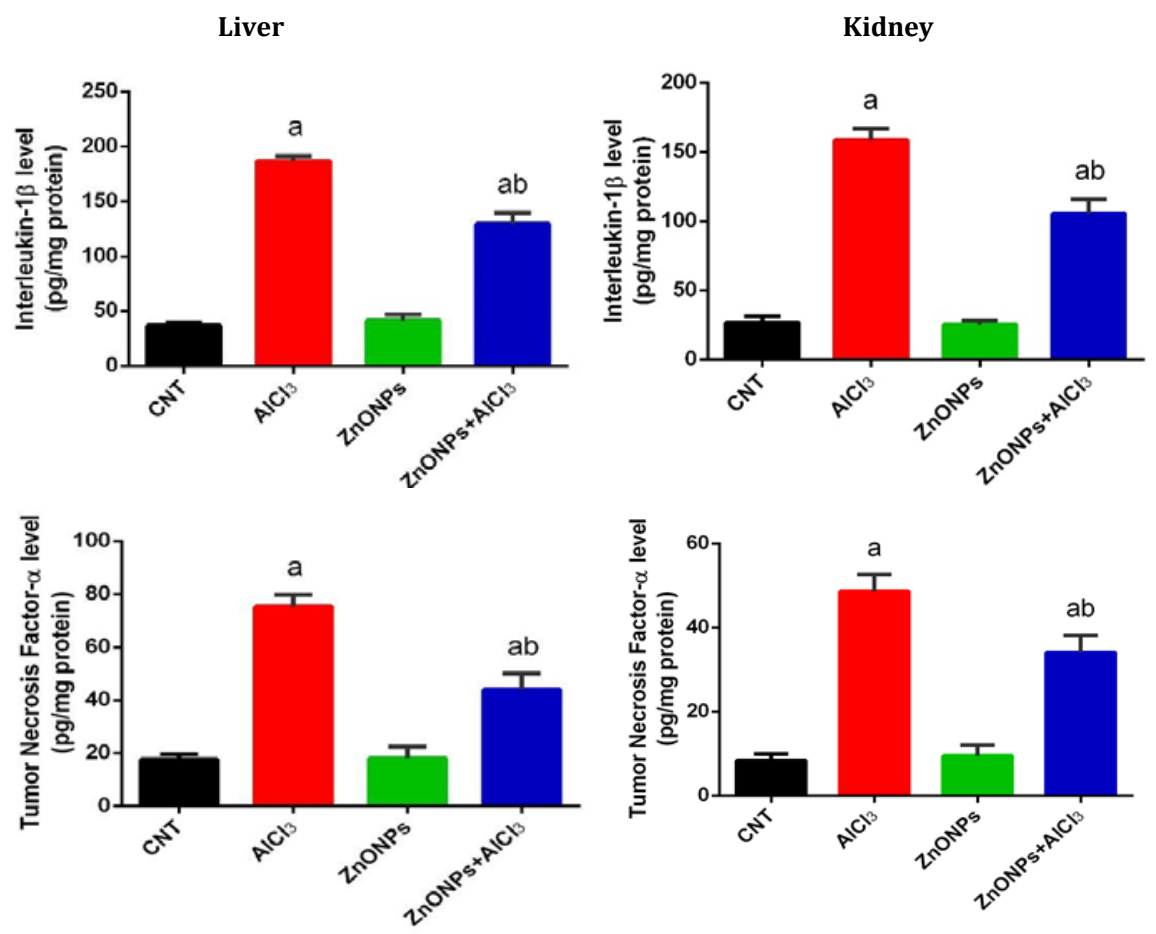

Fig. 4: Effect of zinc oxide nanoparticles (ZnO NPs) and/or aluminum chloride (AlCl3) after daily treatment for $6 \mathrm{w}$, on interleukin-1 (IL-1 $\beta$ ) tumor necrosis factor- $\alpha$ (TNF- $\alpha)$ and levels in liver and kidney of adult male rats. Data are expressed as the mean \pm SD $(n=7)$. a $p<0.05 \mathrm{vs.} \mathrm{the}$ control group; $b$ p $<0.05$ vs. the AlCl3-treated rats using Tukey post hoc test
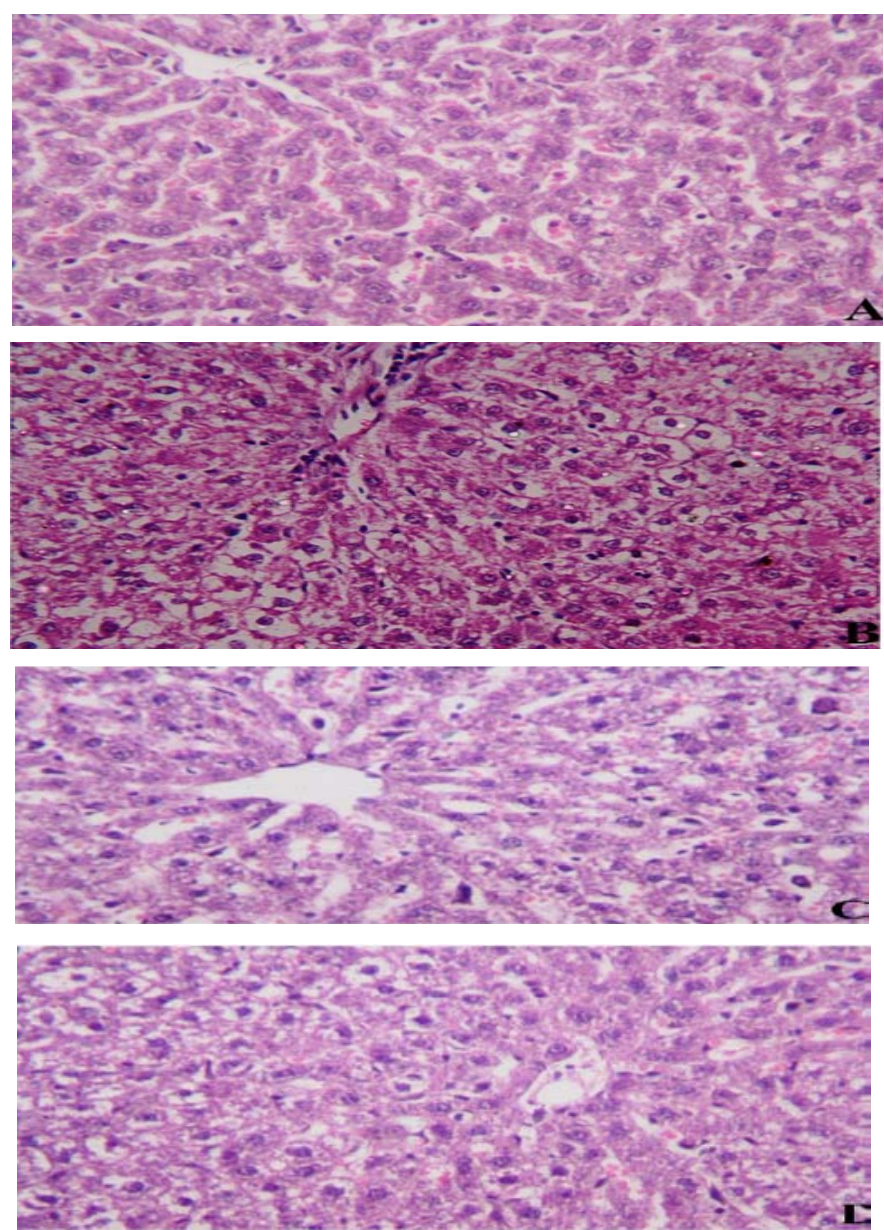

Fig. 5: Photomicrographs of liver tissue. Where $\mathrm{A}$ ) represents control, B) aluminum chloride $\left(\mathrm{AlCl}_{3}\right)$, C) zinc oxide nanoparticles (ZnO NPs) and D) aluminum chlorid $\left(\mathrm{AlCl}_{3}\right)+\mathrm{Zinc}$ oxide nanoparticles (ZnO NPs) 


\section{Effect of ZnO NPs and/or $\mathrm{AlCl}_{3}$ treatment on kidney histopathology}

As shown in fig. 6, the renal tissue of the control and ZnO NPs-treated animals showed an identical kidney structure with normal renal tubules and glomeruli. $\mathrm{AlCl}_{3}$ intoxication for $42 \mathrm{~d}$ resulted in swelling of epithelial cells, edema of the inter-tubular spaces, focal hemorrhage, inflammatory cell infiltration, vacuolation, and development of intraluminal casts as observed previously [5]. Pre-administration of $\mathrm{ZnO}$ NPs minimized the pathological alterations induced by $\mathrm{AlCl}_{3}$ exposure in kidney tissue.
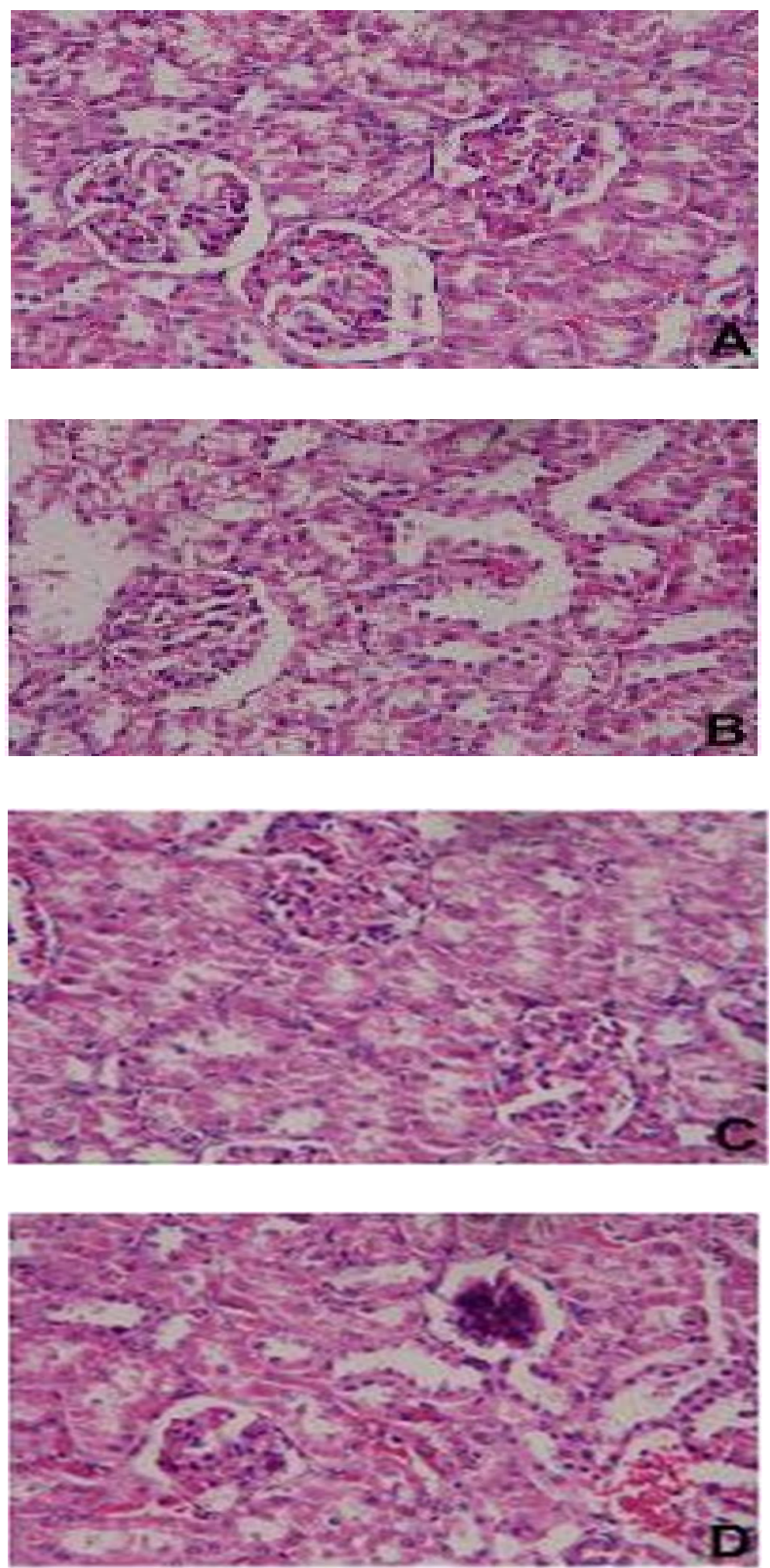

Fig. 6: Photomicrographs of kidney tissue. Where $\mathrm{A}$ ) represents control, B) aluminum chloride $\mathrm{AlCl}_{3}$ ), C) zinc oxide nanoparticles (ZnO NPs) and D) aluminum chloride ( $\left.\mathrm{AlCl}_{3}\right)$ +zinc oxide nanoparticles (ZnO NPs) 
I) Liver
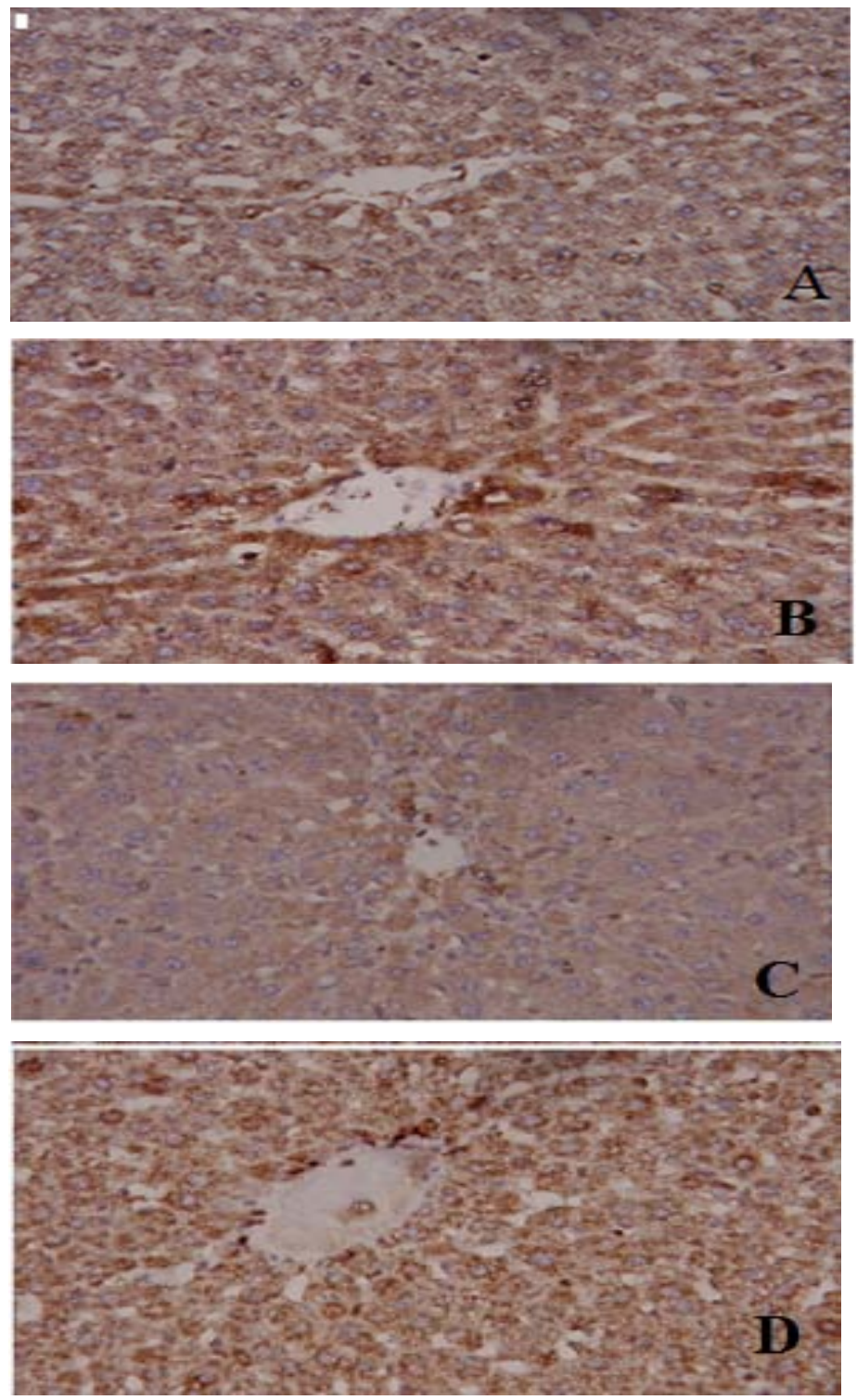

II-Kidney
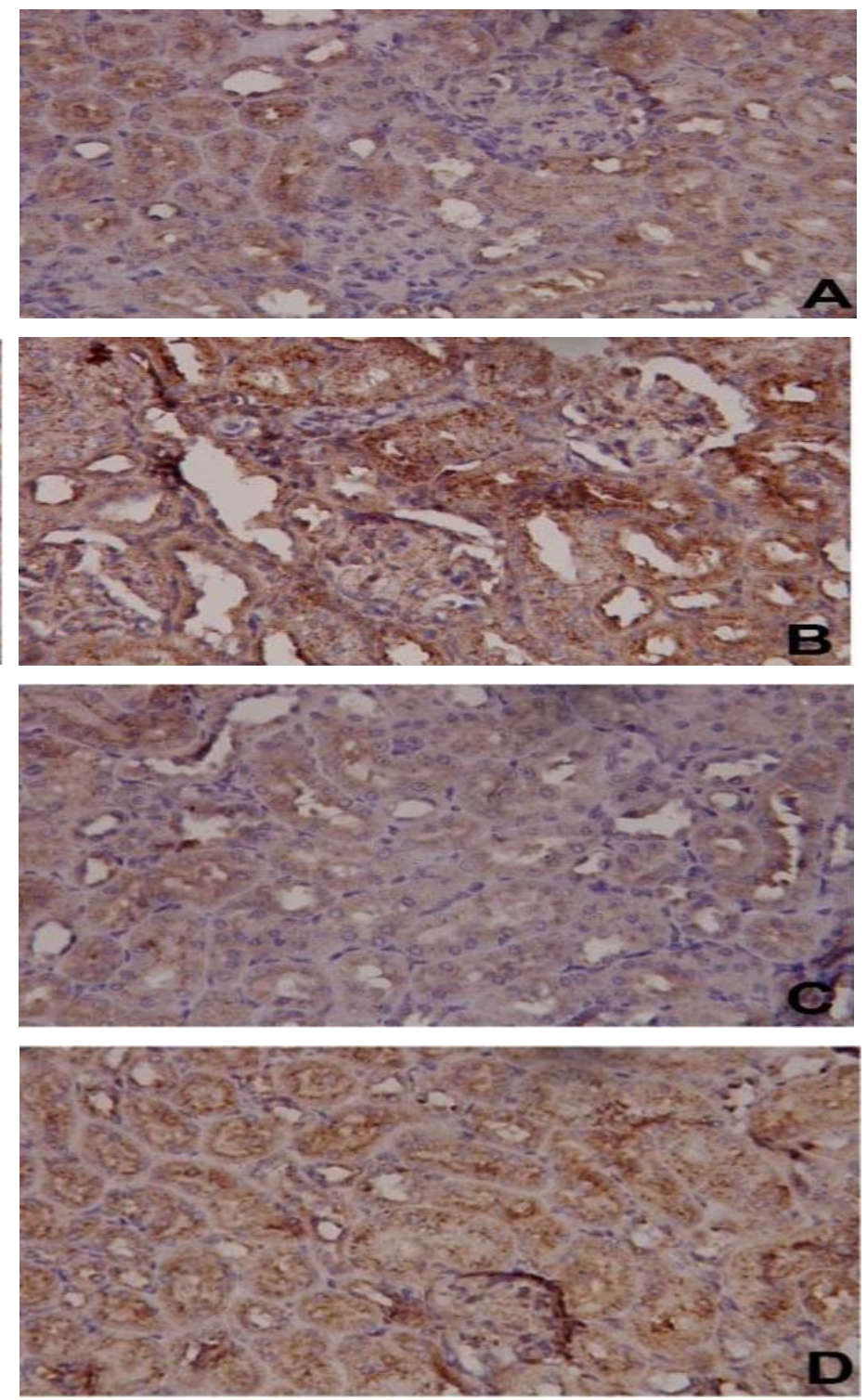

Fig. 7: Examination of the expression of nuclear factor Kappa B (NF-kB) in liver I, and kidney tissue II, using immunohistochemical staining following the administration of zinc oxide nanoparticles (ZnO NPs) and/or aluminum chloride $\left(\mathrm{AlCl}_{3}\right)$ for $6 \mathrm{w}($ magnification $400 \times)$. A) control, B) aluminum chloride, C) zinc oxide nanoparticles and D) aluminum chloride+zinc Oxide nanoparticles

\section{Effect of ZnO NPs and/or $\mathrm{AlCl}_{3}$ treatment on NF-kB expression}

The immuno-reactivity of NF- $\mathrm{BB}$ was estimated in the hepato-renal tissue to follow the molecular mechanism of the anti-inflammatory effect of $\mathrm{ZnO}$ NPs. Rats intoxicated with $\mathrm{AlCl}_{3}$ showed overexpression of NF- $\mathrm{kB}$, as compared to the control group. On the contrary, expression of NF-KB was down-regulated markedly in $\mathrm{ZnO} \mathrm{NPs}$ and $\mathrm{ZnO} \mathrm{NPs}+\mathrm{AlCl}_{3}$-treated rats, when compared against $\mathrm{AlCl}_{3}$-treated rats. These findings indicate the anti-inflammatory activity of ZnO NPs used dose (fig. 7).

\section{DISCUSSION}

The liver plays a major role in the detoxification process; hepatocytes were considered as a massive detoxification center protecting the body from the deleterious effects [30]. Studies indicated that nanoparticles have superior physicochemical, mechanical, thermal and biological properties and also, better catalytic activities as compared to bulk materials, therefore zinc nanoparticles were reported to have various biological and pharmacological activities; such as antimicrobial, antioxidant, anti-inflammatory, anti-tumor, hepato-renal protective and immunomodulatory activity $[11,12,31-36]$.

Data availability concerning the accumulation of ZnO NPs in rat liver and kidney following $\mathrm{AlCl}_{3}$ intoxication was limited. The present results indicated that ZnO NPs decreased $\mathrm{Al}$ accumulation in hepato-renal tissue, while increased $\mathrm{Zn}$ content in both tissues when assayed in $\mathrm{ZnO}$ $\mathrm{NPs}+\mathrm{AlCl}_{3}$-treated rats group. The accumulation of NPs in the liver and kidney of mice after intravenous administration was documented [37]. Likely, an increase in the nano-zinc level in different tissues of mice was also reported [38]. Authors showed that ZnO NPs may be absorbed into circulation within $30 \mathrm{~min}$, after i. p. injection, and remained in serum for $72 \mathrm{~h}$ and ZnO NPs were bio-distributed into the liver, spleen, and kidney thereby, spreading to the heart, lung, and testes [38].

The hepato-renal tissues were considered as target organs for ZnO NPs accumulation and toxicity in rats [39]. The observed increase in $\mathrm{Zn}$ concentration in the hepato-renal tissue, in the present study, could be attributed to their preferential passage through the lymphatic system, 
owing to permeability differences [40] and their high surface reactivity, small size, and shape, which easily cross cell membranes to interact with biomolecules leading to disruption of trace elements homeostasis [41, 42]. Also, to the first-pass effects, as a previous study [43] showed fast dissolution of zinc NPs in the stomach was found to increase zinc level, in the systemic circulation of $\mathrm{CdCl}_{2}$-hepatorenal injured mice treated with ZnO NPs and followed by zinc ions redistribution from the liver to other organs. Another reason for $\mathrm{Zn}$ accumulation was the induction of tissues metallothionein (cytosolic cysteine-rich proteins, powerful scavenger of free radicals) [44] for controlling metal homeostasis to maintain cell survival in response to various stimuli [39], and also to the role of $\mathrm{Zn}$ in the synthesis, storage, and secretion of insulin [45].

Liver enzymes and kidney functions (ALT, AST, Bil, urea, and creatinine) in serum were considered as important serum parameters for investigating animal health [46]. Biochemical analysis of liver and kidney function parameters of $\mathrm{AlCl}_{3}$-treated rats indicated their marked elevation, and these results were supported by histopathological examination of the hepato-renal tissue of rats treated with $\mathrm{AlCl}_{3}$, which indicated altered hepatic histo-architecture after $6 \mathrm{w}$ of treatment appearing as vacuolated hepatocytes and leukocytes infiltration. Examined kidney sections showed swelling of epithelial cells, edema of the inter-tubular spaces, focal hemorrhage, inflammatory cell infiltration, and vacuolization. Observations of the present study were following previous studies [47, 5]. These changes were attributed to the altered hepatic cell membrane permeability, increased MDA and NO levels, as reported also in the present study, as $\mathrm{AlCl}_{3}$ intoxication produces an excess of oxygen-free radicals and alters physiological function which plays an important role in cellular membrane damage through free radical chain reaction mechanism [47, 5]. Data from $\mathrm{ZnO} \mathrm{NPs}+\mathrm{AlCl}_{3}$-treated rats group, concerning liver and kidney functions (AST, ALT, Bil, urea, and creatinine) and evaluation of the antioxidant enzymes activity in rat hepatic and renal tissues, indicated the potential ameliorative effect of ZnO NPs administration (10 $\mathrm{mg} / \mathrm{kg}$ body weight) with their particular size, on the hepato-renal tissues of $\mathrm{AlCl}_{3}$-intoxicated rats, reflecting their role in protecting the hepato-renal tissue function against Al-intoxication.

The decreased GSH content and antioxidant enzyme activities (SOD, CAT, GPx and GR) found in the hepato-renal tissues of $\mathrm{AlCl}_{3}$-treated rats agreed with previous studies $[48,5]$. Meanwhile, the antioxidant enzymes activities of SOD, CAT, GR, and GPx in liver of ZnO NPs-treated rats group showed their tendency to elevate, suggesting that administration of ZnO NPs alone may potentiate the antioxidant status in rats either in the liver or kidney of $\mathrm{ZnO}$ NPs-treated group as $\mathrm{ZnO}$ NPs may induce highly reactive oxygen species, which cause oxidative damage to animal cells [49]. Histopathological examination of $\mathrm{ZnO}$ NPs-treated rats supported the biochemical analysis, indicating disruption of hepatic cords and vacuolization. Moreover, ZnO NPs toxic effect of on liver enzymes was reported [50], as ALT and AST are located primarily in the cytosol of hepatocytes [49]. These results reveal that $\mathrm{ZnO}$ NPs may interrupt the functions of liver cells, due to excess zinc inside cells leading to apoptosis [51] taking into consideration using ZnO NPs with different morphological properties. Zinc also was reported to maintain the activity of tumor suppressor gene $\mathrm{p} 53$ thus regulating apoptosis activity, and helping inactivation of the caspase-6 enzyme responsible for apoptosis [52].

The histopathological changes in the hepato-renal tissue of the $\mathrm{ZnO}$ $\mathrm{NPs}+\mathrm{AlCl}_{3}$-treated rats group, in the present work, were found to decrease and this could be attributed to decreased lipid peroxidation, enhanced antioxidant enzymes (CAT and SOD) and preserved GSH content in both tissues. As zinc was reported to play a vital role in cellular GSH regulation and cellular antioxidant defense [53], controlling free radicals and oxidative stress for SOD activity which was documented to have $\mathrm{Zn}^{2+}$ and $\mathrm{Cu}^{2+}$ in its active site thus playing a crucial role in the defense against oxidative stress. The increased SOD activity in the hepato-renal tissue of $\mathrm{ZnO} \mathrm{NPs}+\mathrm{AlCl}_{3}$ of the present work enhanced the break-down of superoxide into oxygen and hydrogen peroxide thus conserving the superoxide radicals concentration at low levels and this could be attributed to the availability of ZnO NPs [54, 55, 43], thereby increasing the mRNA expression of SOD, CAT, GPx, and GR leading to enhanced activity thus ameliorating oxidative stress [56].
Both SOD and CAT were considered as a defense against oxidative cell injury, as CAT decomposes hydrogen peroxide to water and oxygen. CAT and SOD activities in hepatic and renal tissues were mostly recovered in the co-administered group, while GPX and GR activities were partially ameliorated in both tissues. They were documented for their role in sulfhydryl group's protection against oxidation [57], preservation of intracellular levels of reduced GSH and the reduced production of LPO products [58]. GSH is considered as a substrate for GST and GPx activities, therefore its shortage might cause a diminution in their activities. GST constituted a family of phase II detoxification enzymes specialized for detoxification of xenobiotics and in the signaling cascades [59], while, GPx was involved in converting $\mathrm{H}_{2} \mathrm{O}_{2}$ and organic hydro-peroxides to less reactive products [60]. A decrease in the GST activity might result in xenobiotic accretion; whereas the decrease in the GPx activity might accompany $\mathrm{H}_{2} \mathrm{O}_{2}$ accumulation leading to further inactivation in its activity. SOD, CAT, and GPX constitute a supportive team of enzymes providing defense against ROS [61].

After induction of oxidative stress, many released pro-inflammatory cytokines and chemokines through the inflammatory process were considered as a key event in hepatic stellate cells activation [62, 63], as ROS play a critical role in the activation of cells as messengers in the signal transduction pathways leading to gene expression [64]. Zinc supplementation was reported to inhibit hepatic stellate cells activation after ethanol and acetaldehyde administration, therefore acting as an antioxidant and inhibiting several markers of hepatic stellate cells activation [65]. Besides the role of Zinc in decreasing hepatic lipid peroxidation [66], zinc was documented to reduce transforming growth factor- $\beta$ and to induce epithelial differentiation and fibroblast activation thus protecting the liver against fibrosis [67]. Zinc is a potent inducer of metallothioneins, plays a key role in cellular defense against metal toxicity [68], and involved in phagocytosis, antigen presentation by macrophages, and inflammatory responses [32].

Results of the present study, indicated that ZnO NPs treatment to $\mathrm{AlCl}_{3}$ treated rats decreased IL-1 $\beta$ and TNF- $\alpha$ levels which could be attributed to the anti-inflammatory activity of ZnO NPs that suppress mRNA expression of both cytokines and also to the suppression of inducible nitric synthase, cyclooxygenase- 2 and interleukin- 6 levels [12]. Moreover, reports revealed decreased levels and activity of myeloperoxidase (found in neutrophils; catalyzes the formation of ROS) which affect cytokines production [69, 35]. Furthermore, ZnO NPs were found to enhance T cells functionality, having an adjuvant effect toward $\mathrm{T}$ helper- 2 response, thus increasing production and activation of cytokines [32]. Furthermore, ZnO NPs were found to act as an immuno-modulator by increasing antigen-specific immune reactions in mice, and enhancing antigen-specific antibodies production in serum, especially; immunoglobulin $\mathrm{E}$ and $\mathrm{G}[32,70]$.

The observed ameliorative effect of ZnO NPs on the histopathological changes of the hepato-renal tissue, in $\mathrm{ZnO} \mathrm{NPs}+\mathrm{Al}$ treated rats group could be attributed to decreased lipid peroxidation, enhanced antioxidant enzymes activities (CAT and SOD) and preserved GSH content in hepato-renal tissue. Zinc was found to ameliorate oxidative stress and glutathione depletion and involved in all processes concerned with cell protection through activation of DNA repair, thus preventing apoptosis and cell proliferation [71]. ZnO NPs act as an effective adjuvant treatment to chemotherapeutic drugs that may cause male reproductive dysfunction [31] and as a hepatic cytoprotective agent against Aflatoxin B1 exposure, when used in low doses, by improving the antioxidant activity, and decreasing the free radicals level [72]. Studies also showed suppressed MDA content by ZnO NPs treatment in a dose-dependent manner, thus reducing oxidative stress $[69,35]$, therefore, protecting cell membrane integrity against oxidative stress damage, and increasing antioxidant enzyme levels [73].

The immunohistochemical analysis of the hepato-renal tissue from the Al-treated group indicated overexpression of NF-kB, while sections from the $\mathrm{ZnO} \mathrm{NPs}+\mathrm{AlCl} 3$-treated rats group showed decreased expression, evidenced in the present study by decreased NO, Il- $\beta$ and TNF- $\alpha$ levels of the same group. Balanced cell survival and cell death were reported to be created through Zinc channels via controlling free and intracellular zinc movements [74]. Due to their unique properties, ZnO NPs being bioavailable, biocompatible with high solubility and may localize in many 
tissues for cellular cycle regulation and cellular homeostasis maintenance, as they were supposed to mimic biomolecules' activity [75]. Moreover, ZnO NPs exposure suppressed NF- $\mathrm{KB}$ activity and translocation of nuclear ion of NF-kB and p65 in LPS-induced RAW macrophages, together with decreased transcription of cellular proteins leading to inhibition of NF- $\kappa B$, thereby suppressing IL-1 $\beta$ and TNF- $\alpha$ production [76]. Furthermore, ZnO NPs may exert an immune-regulatory role by blocking the caspase- 1 enzyme in activated mast cells leading to the release of different inflammatory mediators and NF- $\kappa B$ as well [36].

\section{CONCLUSION}

Zinc Oxide nanoparticles ameliorated $\mathrm{AlCl}_{3}$-induced hepato-renal toxicity via increasing Zinc accumulation in the hepato-renal tissue and decreasing aluminum disposition. Also, decreasing lipid peroxidation, nitric oxide production, and pro-inflammatory cytokines level (IL-1 $\beta$ and TNF- $\alpha$ ), increasing antioxidant molecule and antioxidant enzymes activity and decreasing nuclear factor-KB expression, markedly.

\section{ETHICS}

This study was reviewed and approved by the Animal Ethics Committee of Helwan University with registration number HU2017/Z/09. All the data are restricted to the principal investigators and solely used for research purposes. The study was conducted in compliance with the ethical principles outlined in the Declaration of Helsinki.

\section{FUNDING}

This research received no specific grant from any funding agency in the public, commercial or not-for-profit sectors.

\section{AUTHORS CONTRIBUTIONS}

All 3 authors participated in the practical work and writing of the manuscript. All authors have complete access to the study data that support the publication.

\section{CONFLICT OF INTERESTS}

The authors declare that they have no conflict of interest

\section{REFERENCES}

1. Verstraeten S, Aimo L, Oteiza PI. Aluminium and lead: molecular mechanisms of brain toxicity. Arch Toxicol 2008;82:789-802.

2. Bhadauria M. Combined treatment of HEDTA and propolis prevents aluminum-induced toxicity in rats. Food and chemical toxicology. Br Ind Biol Res Assoc 2012;50:2487-95.

3. Willhite CC, Karyakina NA, Yokel RA, Yenugadhati N, Wisniewski TM, Arnold IM, et al. Systematic review of potential health risks posed by pharmaceutical, occupational and consumer exposures to metallic and nanoscale aluminum, aluminum oxides, aluminum hydroxide and its soluble salts. Crit Rev Toxicol 2014;(44 Suppl 4):1-80.

4. Turkey H, Yousef MI, Biyikoglu F. Propolis prevents aluminuminduced genetic and hepatic damages in rat liver. Food Chem Toxicol 2010;48:2741-6.

5. Abdel Moneim AE, Othman MS, Mahmoud SM, El-Deib KM Pomegranate peel attenuates aluminum-induced hepatorenal toxicity. Toxicol Mech Methods 2013;23:624-33.

6. El-Kenawy AM, Osman HEH, Daghestani MH. Role of propolis (bee glue) in improving histopathological changes of the kidney of rat treated with aluminum chloride. Environ Toxicol 2014;29:100010.

7. Mahitha B, Raju BDP, Mallikarjuna K, Durga Mahalakshmi C, Sushmal N, Bacopa monniera NJ. Stabilized silver nanoparticles attenuates oxidative stress induced by aluminum in albino mice. J Nanosci Nanotech 2015;15:1101-9.

8. Narayanan KB, Park HH. Pleiotropic functions of antioxidant nanoparticles for longevity and medicine. Adv Coll Sci 2013;201202:30-42.

9. Abhinaya SR, Padmini R. Biofabrication of zinc oxide nanoparticles using pterocarpus marsupium and its biomedical applications. Asian J Pharm Clin Res 2019;12:245-9.

10. Jacob V, Rajiiv P. In vitro analysis: the antimicrobial and antioxidant activity of zinc oxide nanoparticles from Curcuma longa. Asian J Pharm Clin Res 2019;12:200-4.
11. Manyasree D, Kiranmyi P, Kolli VR. Characterization and antibacterial activity of $\mathrm{ZnO}$ nanoparticles synthesized by the coprecipitation method. Int J Appl Pharm 2018;10:224-8.

12. Nagajyothi PC, Cha SJ, Yang IJ, Sreekanth TV, Kim KJ, Shin HM. Antioxidant and anti-inflammatory activities of zinc oxide nanoparticles synthesized using Polygala tenuifolia root extract. J Photochem Photobiol Biol 2015;146:10-7.

13. Najafzadeh $\mathrm{H}$, Ghoreishi SM, Mohammadian B, Rahimi E, Afzalzadeh MR, Kazemi Varnamkhasti M, et al. Serum biochemical and histopathological changes in liver and kidney in lambs after zinc oxide nanoparticles administration. Vet World 2013;6:534-7.

14. Abdel Moneim AE. Indigofera oblongifolia prevents lead acetateinduced hepatotoxicity, oxidative stress, fibrosis and apoptosis in rats. PLoS One 2016;11:1-18.

15. NIH (National Institute Of Health). Memorandum of Understanding Among the Animal and Plant Health Inspection Service USDA and the Food and Drug Administration, US Department of Health and Human Services and the National Institutes of Health Concerning Laboratory Animal Welfare. Office of Extramural Research: NIH, Bethesda; 2006.

16. NIH (National Institutes of Health). Memorandum of Understanding Between the Office of Laboratory Animal Welfare, National Institutes of Health, US Department of Health and Human Services and the Office of Research Oversight and the Office of Research and Development, Veterans Health Administration, US Department of Veterans Affairs Concerning Laboratory Animal Welfare. Office of Extramural Research: NIH, Bethesda; 2007.

17. Kubaszewski L, Ziola Frankowska A, Frankowski M, Nowakowski A, Czabak-Garbacz R, Kaczmarczyk J, et al. Atomic absorption spectrometry analysis of trace elements in degenerated intervertebral disc tissue. Med Sci Mon 2014;20:2157-64.

18. Reitman S, Frankel SA. Colorimetric method for the determination of serum glutamic oxaloacetic and glutamic pyruvic transaminases. Am J Clin Path 1957;28:56-63.

19. Walter M, Gerade H. Bilirubin assay. Microchem J 1970;15:231-6.

20. Fawcett JK, Scott JE. A rapid and precise method for the determination of Urea. J Clin Path 1960;13:156-9.

21. Schirmeister J, Willmann H, Kiefer H. Determination of creatinine in serum. D Med Wochen 1964;89:1940

22. Ohkawa H, Ohishi N, Yagi K. Assay for lipid peroxides in animal tissues by thiobarbituric acid reaction. Anal Biochem 1979;95:351-8.

23. Green LC, Wagner DA, Glogowski J, Skipper PL, Wishnok JS, Tannenbaum SR. Analysis of nitrate, nitrite, and $\left[{ }^{15} \mathrm{~N}\right]$ nitrate in biological fluids. Anal Biochem 1982;126:131-8.

24. Ellman GL. Tissue sulfhydryl groups. Arch Biochem Biophys 1959;82:70-7.

25. Sun Y, Oberley LW, Li Y. A simple method for clinical assay of superoxide dismutase. Clin Chem 1988;34:497-500.

26. Luck H. Catalase. In: HU Bergmeyer. Ed. Methods of enzymatic analysis. Academic Press: New York; 1965. p. 855-88.

27. Paglia DE, Valentine WN. Studies on the quantitative and qualitative characterization of erythrocyte glutathione peroxidase. J Lab Clin Med 1967;70:158-69.

28. Factor VM, Kiss A, Woitach JT, Wirth PJ, Thorgeirsson SS. Disruption of redox homeostasis in the transforming growth factor-alpha/c-myc transgenic mouse model of accelerated hepatocarcinogenesis. J Biol Chem 1998;273:15846-53.

29. Bancroft J, Gamble M. Bancroft's theory and practice of histological techniques. Eds. Vol. 6th Edition. Elsevier, London: Churchill Livingstone; 2008.

30. Mescher MJA. Basic histology: text and atlas. 13th Ed. McGrawHill Education; 2013. p. 329-39.

31. Badkoobeh P, Parivar K, Kalantar SM, Hosseini SD, Salabat A. Effect of nano-zinc oxide on doxorubicin-induced oxidative stress and sperm disorders in adult male wistar rats. Iran J Reprod Med 2013;11:355-64.

32. Roy R, Kumar S, Verma AK, Sharma A, Chaudhari BP, Tripathi A, et al. Zinc oxide nanoparticles provide an adjuvant effect to ovalbumin via a Th2 response in Balb/c mice. Int Immun 2014;26:159-72.

33. Bisht G, Rayamajhi S. ZnO nanoparticles: a promising anticancer agent. Nanobiomed 2016;3:9. 
34. Yuan Y, Cai T, Xia X, Zhang RP, Cai CY. Nanoparticle delivery of anticancer drugs overcomes multidrug resistance in breast cancer, Drug Delivery 2016;23:3350-7.

35. Li J, Chen H, Wang B, Cai C, Yang X, Chai Z, et al. ZnO nanoparticles act as supportive therapy in DSS-induced ulcerative colitis in mice by maintaining gut homeostasis and activating Nrf2 signaling. Sci Rep 2017;7:43126.

36. Agarwal H, Nakara A, Shanmugam VK. Anti-inflammatory mechanism of various metal and metal oxide nanoparticles synthesized using plant extracts. Rev Biomed Pharmacoth 2019;109:2561-72.

37. Chen JK, Shih MH, Peir JJ. The use of radioactive zinc oxide nanoparticles in the determination of their tissue concentrations following intravenous administration in mice. Analyst 2010;135:1742-6.

38. Li CH, Shen CC, Cheng YW, Huang SH, Wu CC, Kao CC, et al. Organ biodistribution, clearance, and genotoxicity of orally administered zinc oxide nanoparticles in mice. Nano Toxicol 2012;6:746-56.

39. Amara S, Ben Slama I, Mrad I, Rihane N, Khemissi W, El Mir L, et al. Effects of zinc oxide nanoparticles and/or zinc chloride on biochemical parameters and mineral levels in rat liver and kidney. Hum Exp Toxicol 2014;33:1150-7.

40. Liu J, Wong HL, Moselhy J, Bowen B, Wu XY, Johnston MR. Targeting colloidal particulates to thoracic lymph nodes. Lung Can 2006;51:377-86.

41. Xiong D, Fang T, Yu L, Sima X, Zhu W. Effects of nano-scale TiO2, ZnO and their bulk counterparts on zebrafish: acute toxicity, oxidative stress, and oxidative damage. Sci Environ 2011;409:1444-52.

42. Lee CM, Jeong HJ, Yun KN, Kim DW, Sohn MH, Lee JK. Optical imaging to trace near-infrared fluorescent zinc oxide nanoparticles following oral exposure. Int J Nanomed 2012;7:3203-9.

43. Gao S, Wang X, Wang S, Zhu S, Rong R, Xu X. Complex effect of zinc oxide nanoparticles on cadmium chloride-induced hepatotoxicity in mice: protective role of metallothionein. Metall 2017;1:706-14.

44. Suntres ZE, Lui EM. Biochemical mechanism of metallothioneincarbon tetrachloride interaction in vitro. Biochem Pharmacol 1990;39:833-40.

45. Yaghmaei P, Esfahani Nejad H, Ahmadi R, Hayati Roodbari N Ebrahim Habibi A. Maternal zinc intake of wistar rats has a protective effect in the alloxan-induced diabetic offspring. J Physiol Biochem 2013;69:35-43.

46. Canli EG, Canli M. Effects of aluminum, copper, and titanium nanoparticles on some blood parameters in wistar rats. Turk J Zool 2017;41:259-66.

47. Wong Ekkabut J, Xu Z, Triampo W, Tang IM, Tieleman DP, Monticelli L. Effect of lipid peroxidation on the properties of lipid bilayers: a molecular dynamics study. Biophys J 2007;93:4225-36.

48. Shati AA, Alamri SA. Role of saffron (Crocus sativus L.) and honey syrup on aluminum-induced hepatotoxicity. Sau Med J 2010;31:1106-13.

49. Sharma V, Singh P, Pandey AK, Dhawan A. Induction of oxidative stress, DNA damage and apoptosis in mouse liver after sub-acute oral exposure to zinc oxide nanoparticles. Mut Res Genet Toxicol Env Mut 2012;745:84-91.

50. Fazilati M. Investigation toxicity properties of zinc oxide nanoparticles on liver enzymes in the male rat. Eur J Exp Biol 2013;3:97-103.

51. John E, Laskow TC, Buchser WJ, Pitt BR, Basse PH. Zinc in innate and adaptive tumor immunity. J Transl Med 2010;8:118-20.

52. Ng KW, Khoo SP, Heng BC. The role of the tumor suppressor p53 pathway in the cellular DNA damage response to zinc oxide nanoparticles. Biomat 2011;32:8218-25.

53. Parat MO, Richard M, Beani, JC, Favier A. Involvement of zinc in Intracellular oxidant/antioxidant balance. Biol Trace Elem Res 1997;60:187-204.

54. Fridovich I. Superoxide anion radical (0. 2), superoxide dismutases, and related matters. J Biol Chem 1997;272:18515-7.
55. Peixoto EB, Pessoa BS, Biswas SK, Lopes de Faria JB. Antioxidant SOD mimetic prevents NADPH oxidase-induced oxidative stress and renal damage in the early stage of experimental diabetes and hypertension. Am J Neph 2009;29:309-18.

56. Afifi M, Abdelazim AM. Ameliorative effect of zinc oxide and silver nanoparticles on the antioxidant system in the brain of diabetic rats. Asian Pac J Trop Biomed 2015;5:874-7.

57. Bray TM, Bettger WJ. The physiological role of zinc as an antioxidant. Free Rad Biol Med 1990;8:281-91.

58. Bao B, Ahmad A, Azmi A, Li Y, Prasad A, Sarkar FH. The biological significance of zinc in inflammation and aging. In: Inflammation, Advancing age and Nutrition: Research and Clinical Interventions. 1st ed. Edited by Rahman I, Bagchi D. New York, NY, Elsevier Inc, Chapter 2; 2013. p. 15-27.

59. Habig WH, Pabst MJ, Jakoby WB. Glutathione S-transferases the first enzymatic step in mercapturic acid formation. J Biol Chem 1974;249:7130-9.

60. Halliwell B, Gutteridge JMC. Free radicals in biology and. Oxford University Press: New York; 1999.

61. Pigeolet E, Corbisier P, Houbion A, Lambert D, Michiels C, Raes M, et al. Glutathione peroxidase, superoxide dismutase, and catalase inactivation by peroxides and oxygen-derived free radicals. Mech Age Development 1990;15:283-97.

62. Greenwel P, Dominguez Rosales JA, Mavi G, Rivas Estilla AM, Rojkind M. Hydrogen peroxide: a link between acetaldehyde- $\alpha 1$ (i) collagen gene up-regulation and oxidative stress in mouse hepatic stellate cells. Hepatol 2000;31:109-16.

63. Pinzani M, Macias Barragan J. Update on the pathophysiology of liver fibrosis. Exp Rev Gastroent Hep 2010;4:459-72.

64. Dagher Z, Garcon G, Billet S. Role of nuclear factor-kappa B activation in the adverse effects induced by air pollution particulate matter (PM2.5) in human epithelial lung cells (L132) in culture. J Appl Toxicol 2007;27:284-90.

65. Szuster Ciesielska A, Plewka K, Daniluk J, Kandefer Szerszen M. Zinc supplementation attenuates ethanol-and acetaldehydeinduced liver stellate cell activation by inhibiting reactive oxygen species (ROS) production and by influencing intracellular signaling. Biochem Pharmacol 2009;78:301-14.

66. Situnayake RD, Crump BJ, Thurnham DI, Davies JA, Gearty J, Davis M. Lipid peroxidation and hepatic antioxidants in alcoholic liver disease. Gut 1990;31:1311-7.

67. Sorensen Zender I, Bhayana S, Susnik N, Rolli V, Batkai S, Arpita B, et al. Zinc- $\alpha 2$-glycoprotein exerts antifibrotic effects in kidney and heart. J Am Soc Neph 2015;26:2659-68.

68. Moos PJ, Olszewski K, Honeggar M. Responses of human cells to $\mathrm{ZnO}$ nanoparticles: a gene transcription study. Metall 2011;3:1199-211.

69. Kim MH, Seo JH, Kim HM, Jeong HJ. Aluminum-doped zinc oxide nanoparticles attenuate the TSLP levels via suppressing caspase1 in activated mast cells. J Biom Appl 2016;30:1407-16.

70. Pei X, Xiao Z, Liu L, Wang G. Effects of dietary zinc oxide nanoparticles supplementation on growth performance, zinc status, intestinal morphology, microflora population, and immune response in weaned pigs. J Sci Food Agric 2019;99:1366-74.

71. Ho E. Zinc deficiency, DNA damage and cancer risk. J Nutr Biochem 2004;15:572-8

72. Atef HA, Mansour MK, Ibrahim EM. Efficacy of zinc oxide nanoparticles and curcumin in amelioration the toxic effects in aflatoxicated rabbits. Int J Curr Microl Appl 2016;5:795-818.

73. Dawei AI, Zhisheng W, Anguo Z. Protective effects of Nano-ZnO on the primary culture mice intestinal epithelial cells in in vitro against oxidative injury. J Anim Vet Adv 2009;8:1964-7.

74. Dhawan DK, Chadha VD. Zinc: a promising agent in dietary chemoprevention of cancer. India J Med Res 2010;132:676-82.

75. Elshama SS, Abdallah ME, Abdel Karim RI. Zinc oxide nanoparticles: therapeutic benefits and toxicological hazards. Open Nanomed J 2018;5:16-22.

76. Kim MH, Jeong HJ. Zinc oxide nanoparticles suppress LPS-Induced $N F-\kappa B$ activation by inducing A20, a negative regulator of NF- $\kappa \mathrm{B}$, in RAW 264.7 macrophages. J Nanosci Nanotech 2015;15:6509-15. 